\title{
The Impact of Deregulation on the Employment and Wages of Airline Mechanics
}



\section{David Card}

Industrial and Labor Relations Review, Vol. 39, No. 4. (Jul., 1986), pp. 527-538.

Stable URL:

http://links.jstor.org/sici?sici=0019-7939\%28198607\%2939\%3A4\%3C527\%3ATIODOT\%3E2.0.CO\%3B2-P

Industrial and Labor Relations Review is currently published by Cornell University, School of Industrial \& Labor Relations.

Your use of the JSTOR archive indicates your acceptance of JSTOR's Terms and Conditions of Use, available at

http://www.jstor.org/about/terms.html. JSTOR's Terms and Conditions of Use provides, in part, that unless you have obtained prior permission, you may not download an entire issue of a journal or multiple copies of articles, and you may use content in the JSTOR archive only for your personal, non-commercial use.

Please contact the publisher regarding any further use of this work. Publisher contact information may be obtained at http://www.jstor.org/journals/cschool.html.

Each copy of any part of a JSTOR transmission must contain the same copyright notice that appears on the screen or printed page of such transmission.

The JSTOR Archive is a trusted digital repository providing for long-term preservation and access to leading academic journals and scholarly literature from around the world. The Archive is supported by libraries, scholarly societies, publishers, and foundations. It is an initiative of JSTOR, a not-for-profit organization with a mission to help the scholarly community take advantage of advances in technology. For more information regarding JSTOR, please contact support@jstor.org. 


\title{
THE IMPACT OF DEREGULATION ON THE EMPLOYMENT AND WAGES OF AIRLINE MECHANICS
}

\author{
DAVID CARD*
}

\begin{abstract}
This paper describes the effects of deregulation on negotiated wage rates and employment levels of aircraft mechanics in the scheduled airline industry between 1978 and 1984. A firm-by-firm analysis of the established trunk airlines shows relatively small changes in real wage rates since 1978, and only recent changes in interfirm wage differentials. Employment growth rates, however, have varied widely, both among the established trunk airlines and between them and the new-entrant and former local service airlines. The data suggest that deregulation shifted 5,000 to 7,000 maintenance jobs from the established trunks to the smaller airlines. The shift may have reduced average hourly earnings of mechanics in the industry by as much as 5 percent below the level they would have reached in the absence of deregulation.
\end{abstract}

$\mathbf{T}$ HE recent experience of the airline industry provides a remarkable case study for the analysis of wage and employment outcomes under trade unions. Since passage of the Airline Deregulation Act in 1978, the relative output of the trunk ${ }^{1}$ airlines has steadily declined, while that of new entrants and former local service carriers has steadily increased. These changes have been associated with substantial reductions in employment at the trunks and widely

\footnotetext{
*The author is Assistant Professor of Economics at Princeton University. He thanks Richard Johnson for supplying some of the data for this study, Robert LaLonde and Dan Sichel for assistance, and George Jakubson for helpful comments and suggestions.

${ }^{1}$ Before 1981 the Civil Aeronautics Board categorized airlines into trunks, local-service airlines, and a variety of other designations (such as All-Cargo Carriers, Alaskan Carriers, and Hawaiian Carriers). The trunk airlines included the largest firms in the industry, with authority to service major domestic and international routes. In 1978 the trunks were American, Braniff, Continental, Delta, National, Northwest, Pan American, Trans World, United, and Western. In this paper, I use the term trunks to refer to these airlines plus USAir.
}

publicized contract renegotiations, often involving wage concessions or two-tiered wage schedules.

This paper describes the impact of deregulation on the wage rates and employment of airline mechanics at the trunk airlines between 1978 and $1984 .^{2}$ The analysis is preliminary since the full effect of deregulation has not yet been felt, and mechanics' wages are established in longterm contracts that adjust slowly to external shocks. Nevertheless, the experience of airline mechanics in the first six years of deregulation yields a number of insights into the response of trade unions to an increase in product market competition.

Among the three major groups of skilled

\footnotetext{
${ }^{2}$ There is a growing literature on the effect of deregulation on industrial relations in the airline industry. See in particular the papers by Hendriks, Feuille, and Szerszen (1980), Northrup (1983), and Cappelli (1985). Cordes, Goldfarb, and Johnson (1984) describe the likely effect of job loss compensation provisions of the Airline Deregulation Act. Bailey, Graham, and Kaplan (1985) give an overview of deregulation's ef fect on the industry as a whole.
} 
employees in the airline industry (pilots, flight attendants, and mechanics), airline mechanics are atypical. First, their training and skills are relatively easily transferred out of the airline industry. Second, the services of mechanics are relatively easily replaced: many airlines purchase all or part of their maintenance services from outside contractors. Third, employment conditions for many mechanics resemble those of industrial workers: roughly one-half of airline mechanics work at maintenance depots on conventional work schedules. For these reasons, of the three categories of skilled employees, airline mechanics are most similar to unionized workers elsewhere in the economy. It is natural, therefore, to look to the experiences of the mechanics in attempting to draw general conclusions from the deregulatory experience of the airline industry.

\section{Wages and Employment of Airline Mechanics}

The data for this study consist of annual observations on employment, wages, and output at eleven of the largest airline firms in the United States: American, Braniff, Continental, Delta, Eastern, Northwest, PanAm, Transworld, United, USAir, and Western. Mechanics at seven of these airlines are represented by the International Association of Machinists and Aerospace Workers (IAM). Mechanics at American and PanAm are represented by the Transport Workers Union (TWU), mechanics at Western are represented by the Teamsters (IBT), and mechanics at Delta are unorganized. The Machinists and Teamsters also represent mechanics at several smaller airlines and contract maintenance firms. ${ }^{3}$

\section{Wages}

Table 1 presents a wage chronology for nine trunk airlines over the period 1966 to

\footnotetext{
${ }^{3}$ Based on 1984 employment figures for 92 percent of maintenance workers in the industry, the IAM represents 63 percent of airline mechanics, the TWU represents 22 percent, and the IBT represents 5 percent.
}

1985. ${ }^{4}$ The table contains wage rates for certified mechanics at the signing date of each new contract. For comparative purposes, the table also presents contract wage rates for certified aircraft mechanics at Boeing (as an example of an aircraft manufacturing firm), and average wage rates of maintenance mechanics and production workers in manufacturing industries.

A striking feature of the table is the uniformity across airlines in mechanics' wage rates in the years before deregulation. This uniformity persisted through the first two rounds of contract negotiations after deregulation began in 1978: the 1978-79 and 1982-83 rounds (rows 6 and 7 of the table). Very recently, however, wage differentials have opened up in the industry, with significantly lower wage rates at several of the financially troubled airlines. Wage rates at the financially sound airlines have maintained the pattern of equality established in the industry before deregulation. ${ }^{5}$

Several explanations have been offered for the long delay between passage of the Airline Deregulation Act in 1978 and the breakdown of pattern wage bargaining for airline mechanics. On one hand, entry of the new carriers and expansion of the former local-service airlines occurred slowly after 1978. On the other hand, product market competition and downward pressure on labor costs reached an unprecedented level during the 1982 recession, when two of the trunks (Braniff and Con-

\footnotetext{
${ }^{4}$ The wage data in Table 1 were assembled from a variety of sources, including contracts on file at the National Mediation Board and published reports in the Bureau of Labor Statistics' Current Wage Developments and the Bureau of National Affairs' Daily Labor Report. I am grateful to the Airline Division of the IB $T$ for supplying me with copies of the Western Airlines contracts from 1966 to 1981.

${ }^{5}$ The pattern of wages in Table 1 extends to many of the smaller unionized carriers in the industry. For example, the mechanics' wage rate was $\$ 16.25$ in September 1983 in the Ozark Airlines-Airline Mechanics Fraternal Association contract; $\$ 15.91$ in April 1983 in the Piedmont Airlines-IAM contract; $\$ 15.59$ in September 1983 in the Pacific Southwest AirlinesIBT contract; and $\$ 15.91$ in June 1983 in the Republic Airlines-IAM contract. Concessionary contracts were subsequently signed at Pacific Southwest and Republic, whereas Ozark and Piedmont have retained wage parity with the more profitable trunk airlines.
} 





Table 2. Employment and Wage Rates of Airline Mechanics at Scheduled Airlines, 1970, 1975, 1980, and 1984.

\begin{tabular}{|c|c|c|c|c|c|c|}
\hline \multirow[b]{2}{*}{ Date } & \multirow[b]{2}{*}{$\begin{array}{l}\text { Number of } \\
\text { Airlines in } \\
\text { Industry". }\end{array}$} & \multirow[b]{2}{*}{$\begin{array}{c}\text { Number of } \\
\text { Mechanics } \\
\text { and Inspectors }\end{array}$} & \multicolumn{3}{|c|}{ Mechanics' Average Wage Rates ${ }^{\mathrm{b}}$} & \multirow{2}{*}{$\begin{array}{c}\text { Coefficient of } \\
\text { Variation of } \\
\text { Mechanics' } \\
\text { Wage }^{\circ}\end{array}$} \\
\hline & & & $\begin{array}{l}\text { Current } \\
\text { Dollars }\end{array}$ & 1970 Dollars & $\begin{array}{l}\text { Relative to } \\
\text { Contract Rate } \\
\quad \text { at UAL }\end{array}$ & \\
\hline 1. Aug. 1970 & 27 & 38,074 & 5.37 & 5.37 & .98 & .039 \\
\hline $\begin{array}{l}\text { 2. Aug.-Nov. } \\
1975\end{array}$ & 26 & 37,362 & 8.20 & 5.92 & 1.02 & .042 \\
\hline 3. Sept. 1980 & 30 & 39,278 & 12.43 & 5.86 & .97 & .061 \\
\hline 4. June 1984 & 39 & 36,252 & 16.04 & 6.00 & .96 & .144 \\
\hline
\end{tabular}

Source: BLS Industry Wage Surveys: Scheduled Airlines (various issues).

${ }^{a}$ Excludes intra-Alaska and intra-Hawaii carriers.

${ }^{b}$ Wage rates include license premiums and line-service premiums. The contract rate at United Airlines includes the maximum of two license premiums.

'Author's calculations based on reported wage distributions.

tinental) underwent bankruptcy and all the trunks incurred large operating losses. ${ }^{6}$

Some observers have interpreted the recent movement away from a uniform industry wage as a permanent structural change engendered by deregulation. Others have argued that airline-specific wage concessions reflect the interaction of general economic conditions and a newly competitive product market structure, and that improving economic conditions will renew pressure for uniform wages among the carriers. At this stage, however, it is unclear whether wage dispersion will persist or the industry will eventually return to a more uniform wage structure.

Further evidence on the distribution of wage rates within the scheduled airline industry is presented in Table 2. This table presents wage data for airline mechanics from BLS industry wage surveys conducted in 1970, 1975, 1980, and 1984 . Average wage rates in the industry are closely linked to the contract rates reported in Table 1. There is a downward shift in

\footnotetext{
${ }^{6}$ For the economy as a whole, the 1982 recession was deeper but shorter-lived than the 1973-74 recession. In the airline industry, sales as measured by revenue passenger miles were more or less constant between 1973 and 1975 and between 1980 and 1982 (compared with an average annual growth rate of revenue passenger miles of 6.4 percent per year over the 1971-84 period). Real average passenger fares fell about 5 percent between 1974 and 1975, and about 10 percent between 1981 and 1982 .
}

the industry average wage rate relative to the contractual rate at United Airlines (often considered the industry leader in negotiations with mechanics before deregulation) after 1975. Wage dispersion within the industry also increased in the most recent survey, as shown by the doubling of the coefficient of variation of wage rates between 1980 and 1984. The 1984 wage distribution shows a small concentration of wage rates some 20-40 percent below the industry mean wage, whereas the earlier distributions are unimodal and highly concentrated.

Tables 1 and 2 also present evidence on time-series variability of real and relative wage rates of airline mechanics. Outside of the air transport industry, the aircraft and parts industry is a major employer of aircraft mechanics. ${ }^{7}$ The wage chronology for mechanics at Boeing suggests that wage rates have been very similar in the two industries. Relative wage rates between the aircraft assembly and scheduled airline industries did not change between 1978 and 1983. The same conclusion emerges from a comparison of mechanics' wage rates and

\footnotetext{
${ }^{7}$ According to 1980 Census data, 52 percent of aircraft mechanics are employed in the air transportation industry, of which roughly two-thirds are employed in the certified airline industry. Some 20 percent of aircraft mechanics are employed in the aircraft and parts industry, and another 20 percent in the military.
} 
average wage rates of maintenance mechanics or production workers in manufacturing. Relative to either rate, airline mechanics' wages have been more or less constant since the 1969 round of contract negotiations. Relative to the Consumer Price Index, airline mechanics' average wage rates have been approximately constant since 1975 .

The similarity among contract provisions at the major airlines extends to most aspects of compensation, including pensions, vacations, and health plans. In addition, the major airlines that have not negotiated wage concessions since 1982 (American, Northwest, United, and USAir) have all introduced two-tiered wage schedules." Twotiered schedules have also recently spread among the smaller unionized carriers in the industry."

The pattern of the wage data in Table 1 contrasts sharply with the pattern of the firm-specific employment data in Table 3 (") $^{10}$ Although wages remained relatively constant across firms from 1966 to 1983 , employment growth varied substantially. Between 1970 and 1978, for example, mechanics' employment fell about 10 percent at American, Continental, and Transworld, and about 20 percent at United. During the same period, employment grew or remained approximately constant at the other airlines. In spite of this variation across firms in employment demand, airline mechanics were remarkably successful in maintaining a homogeneous wage struc-

\footnotetext{
${ }^{8}$ The schedule at American Airlines, for example, provides approximately 25 percent lower discounted earnings for new hires during their first 12 years with the firm than for incumbent workers with similar qualifications. Two-tiered schedules were introduced in the February 1983 contract at American: in the July 1984 contract at United; in the April 1985 contract at USAir; and in the July 1985 contract at Northwest.

"Two-tiered wage schedules were introduced in April 1982 at Piedmont; in June 1982 at Ozark; and in June 1983 at Republic.

${ }^{10}$ The employment data in Table 3 represent fourth quarter employment in 1970 and year-end employment in 1978 and 1984 for all maintenance and related workers. A comparison of these data with those in Table 2, measuring the employment of mechanics and inspectors recorded in the industry wage surveys, suggests that some $70-80$ percent of maintenance employees are mechanics or inspectors.
}

ture. Until the most recent years there is no indication that mechanics' unions adjusted contractual wage rates in response to firm-specific factors.

The implication of this homogeneous industry wage structure is that a firm-byfirm analysis of wage determination for airline mechanics is likely to be misleading. Several authors have recently estimated models in which unions determine wages at the firm level subject to the constraint imposed by the firm's labor demand function. " Although such a model may be useful in describing wage developments in other industries, and may turn out to be useful in describing developments in the airline industry after 1983, it gives few insights into the homogeneous wage structure that prevailed in this industry before 1983.

\section{Employment}

Table 3 summarizes levels and growth rates of the employment of maintenance workers (about 75 percent of whom are mechanics or inspectors) at 11 major airlines and in the industry as a whole. In 1970 , the trunk airlines accounted for 93 percent of total industry employment. Between 1970 and 1978, maintenance employment at the trunks fell by about 12 percent. During the same period, employment at the local service airlines increased by 70 percent, causing the share of employment at the trunks to fall to 87 percent in 1978. This trend persisted after 1978, with some increase in the relative growth rate of maintenance employment at the nontrunk airlines. In 1984, the trunks' share of industry employment was 80 percent.

To place these employment trends in perspective, Table 4 presents an overview of flight activity in the industry. Because industry output grew during the past 15 years while employment fell, measured output per maintenance employee has increased dramatically. Between 1970 and 1978 productivity increased rapidly at both the larger trunk airlines (where newer widebody aircraft replaced first-generation

\footnotetext{
"See, for example, Dertouzos and Pencavel (1981) or Pencavel (1984).
} 





Table 4. Growth Rates and Shares of Airline Output and Output per Employee, 1970, 1978, and 1984.

\begin{tabular}{|c|c|c|c|c|c|}
\hline \multirow[b]{2}{*}{ Year } & \multicolumn{3}{|c|}{ Available Ton-Miles (millions) } & \multicolumn{2}{|c|}{$\begin{array}{c}\text { Available Ton-Miles Per } \\
\text { Maintenance Worker (millions) }\end{array}$} \\
\hline & $\begin{array}{l}11 \text { Major } \\
\text { Airlines }\end{array}$ & All Carriers & $\begin{array}{c}\text { Output Share- } \\
11 \text { Major } \\
\text { Airlines }\end{array}$ & $\begin{array}{l}11 \text { Major } \\
\text { Airlines }\end{array}$ & All Carriers \\
\hline 1. 1970 & 39,407 & 43,722 & .90 & .858 & .886 \\
\hline 2. 1978 & 50,403 & 56,869 & .89 & 1.245 & 1.228 \\
\hline 3. 1984 & 56,162 & 75,763 & .74 & 1.558 & 1.674 \\
\hline $\begin{array}{l}\text { 4. Growth Rate, } \\
1970-78 \\
\text { (percent/year) }\end{array}$ & 3.1 & 3.3 & - & 4.8 & 4.2 \\
\hline $\begin{array}{l}\text { 5. Growth Rate, } \\
1978-84 \\
\text { (percent/year) }\end{array}$ & 1.8 & 4.9 & - & 3.8 & 5.3 \\
\hline
\end{tabular}

Source: Output data are taken from Civil Aeronautics Board, Air Carrier Traffic Statistics (various issues).

jet aircraft) and the smaller airlines (where smaller jet aircraft replaced turboprop aircraft). After 1978, however, productivity growth slowed at the trunks while it increased sharply in the rest of the industry. Since 1978, the smaller airlines, responding to expanding market opportunities, have significantly increased the length of their flights and the size of their aircraft. ${ }^{12}$ These changes have been associated with rapid increases in ton-miles and seat-miles per departure and per maintenance employee.

Although output and employment shares of the trunks have both declined sharply since 1970 , the drop in output share occurred after 1978, whereas the drop in employment share started earlier. In 1984, the trunks' employment share exceeded their output share by 6 percent. In part, this difference may reflect the contractingout of maintenance services by the smaller

\footnotetext{
${ }^{12}$ For example, Piedmont Airlines increased its available ton-miles and available seat miles at a rate of approximately 28 percent per year from 1978 to 1984. Over the same period, maintenance employment and scheduled departures grew at only 8 percent per year. The increase in capacity came from the replacement of turboprop aircraft by two- and threeengine jet aircraft, and associated increases in seats per aircraft (from 86 in 1978 to 126 in 1984) and flight length (from 181 miles in 1978 to 347 miles in 1984).
}

airlines-often to the trunks themselves. ${ }^{13}$ On balance, however, the output and employment data suggest that most of the decline in the trunks' share of maintenance employment in the industry since 1970 is attributable to the decline in their share of industry output. This hypothesis is tested in the next section using data from four major trunk airlines: American, Eastern, Transworld, and United.

\section{Changes in Productivity of Maintenance Employees}

Between 1978 and 1984, the combined output of the four largest trunk airlines (American, Eastern, Transworld, and United) increased by 14 percent. During the same period, their combined maintenance employment fell 10 percent. Although some of this improved productivity represents a longer-term trend, it is interesting to ask whether deregulation contributed to the rate of growth of maintenance productivity at the airlines. Several recent changes associated with deregulation may have led to an increase in trend productivity growth after 1978. These include the shift toward hub-based routing

\footnotetext{
${ }^{1.3}$ People's Express, for example, employs none of its own airline mechanics.
} 
systems, which permit more centralized line service maintenance, and negotiated changes in work rules and staffing requirements.

In order to investigate the rate of growth of maintenance productivity, I fit a variety of employment functions for mechanics at the four major trunks. ${ }^{14}$ These functions express current maintenance employment in terms of airline-specific constants and trends, as well as lagged employment and current flight activity. The inclusion of lagged employment captures the idea that employment adjusts slowly to output fluctuations. Flight activity is modeled in two alternative ways. In the first case, I represent airline output by departures, and control for the composition of aircraft and routes by including measures of seats per aircraft and flight length. In the second case, I control for aircraft and route composition by including a measure of ton-miles per departure. The latter specification permits maintenance employment to depend on arbitrary combinations of output as measured by departures or available tonmiles.

A preliminary investigation revealed no systematic wage effects on employment levels at the four airlines. In view of the stability of real wage rates over time, however, and in the absence of data on prices of substitutes for mechanics' services, it is not surprising that the estimated wage effects are small and imprecise. I therefore concentrate on the link between employment and output, and changes in output per worker over time.

The estimated employment demand functions are presented in Table 5. The employment functions are fitted as a fourequation seemingly unrelated regression, with equality restrictions on the coefficients of lagged employment and output. ${ }^{15}$ Test results presented in row 7 of Table 5 indicate substantial conformity with the hypothesis of constant returns to scale in

\footnotetext{
${ }^{14}$ The choice of the four major trunks is somewhat arbitrary. Most of the other incumbent trunks were affected by mergers, forced reorganization, or prolonged strikes in 1970-84.

${ }_{1: r}^{1}$ Tests for coefficient equality were insignificant at 20 percent significance levels in all cases.
}

maintenance activities, after controlling for partial-adjustment. ${ }^{16}$ This restriction is therefore imposed on the estimated employment functions in Table 5 .

The first two columns of the table present employment functions with no allowance for changes in productivity growth after 1978. The overall fit of the employment function is similar for the two specifications, and there is no strong basis for choosing between them. The estimated coefficients suggest that a 10 percent increase in output brings about a $6-7$ percent increase in employment within the year, and a proportional change in employment within three years.

The implied decompositions of employment changes between 1978 and 1984 are presented in Table 6. For each airline, two decompositions are presented, depending on the choice of output specification. The decompositions show a declining demand for maintenance employment at all four airlines attributable to secular productivity growth. The productivity component is relatively large at. United Airlines, and is roughly similar between the two specifications for all the airlines except Transworld. The productivity effect is partially offset by increases in the size of aircraft and length of flight, or alternatively by increases in tonmiles per departure. Changes in employment attributable to changes in output are large and negative at Transworld and United, and relatively small at American and Eastern.

Columns (3) and (4) of Table 5 present employment functions that permit airlinespecific shifts in the rate of growth of maintenance productivity after 1978 . The trend shifts are imprecisely measured, and the hypothesis that they are jointly equal to zero

${ }^{16}$ The fitted employment demand functions have the form

$$
\begin{gathered}
\log E_{i t}=a_{i}+b_{i} t+\lambda \log E_{i t-1} \\
+\theta \log F_{i t}+\gamma \mathrm{x}_{i t}+\epsilon_{i t}
\end{gathered}
$$

where $E_{i l}$ represents maintenance employment at airline $i$ in period $t, a_{i}$ and $b_{i}$ are airline-specific constants and trends, $F_{i t}$ represents departures at airline $i$ in period $t, x_{i t}$ represents a control for aircraft and routes, and $\epsilon_{i t}$ is an error term. The hypothesis of a one-toone employment-output relation is represented by $\theta=$ $1-\lambda$. 
Table 5. Maintenance Employment Functions for Four Major Airlines, 1971-84. (standard errors in parentheses)

\begin{tabular}{|c|c|c|c|c|c|c|}
\hline \multirow[b]{3}{*}{ Function } & \multicolumn{6}{|c|}{ Dependent Variables: Logarithm of Maintenance Employment. } \\
\hline & \multicolumn{2}{|c|}{ No Trend Shift } & \multicolumn{2}{|c|}{$\begin{array}{c}\text { Airline-Specific Trend } \\
\text { Shift } \\
\end{array}$} & \multicolumn{2}{|c|}{ Common Trend Shift } \\
\hline & (1) & (2) & (3) & (4) & (5) & (6) \\
\hline 1. Logarithm of Lagged Employment & $\begin{array}{l}.36 \\
(.07)\end{array}$ & $\begin{array}{l}.30 \\
(.07)\end{array}$ & $\begin{array}{l}.33 \\
(.08)\end{array}$ & $\begin{array}{l}.23 \\
(.09)\end{array}$ & $\begin{array}{l}.36 \\
(.07)\end{array}$ & $\begin{array}{l}.25 \\
(.09)\end{array}$ \\
\hline 2. Logarithm of Departures & $\begin{array}{l}.64 \\
(.07)\end{array}$ & $\begin{array}{l}.70 \\
(.07)\end{array}$ & $\begin{array}{l}.67 \\
(.08)\end{array}$ & $\begin{array}{l}.77 \\
(.09)\end{array}$ & $\begin{array}{l}.64 \\
(.07)\end{array}$ & $\begin{array}{l}.75 \\
(.09)\end{array}$ \\
\hline 3. Logarithm of Flight Length & $\begin{array}{l}.10 \\
(.13)\end{array}$ & - & $\begin{array}{l}.18 \\
(.18)\end{array}$ & - & $\begin{array}{l}.17 \\
(.14)\end{array}$ & - \\
\hline $\begin{array}{l}\text { 4. Logarithm of Average Aircraft } \\
\text { Size }\end{array}$ & $\begin{array}{l}.31 \\
(.20)\end{array}$ & - & $\begin{array}{c}.49 \\
(.26)\end{array}$ & - & $\begin{array}{l}.51 \\
(.23)\end{array}$ & - \\
\hline $\begin{array}{l}\text { 5. Logarithm of Ton-Miles per } \\
\text { Departure }\end{array}$ & - & $\begin{array}{l}.28 \\
(.13)\end{array}$ & - & $\begin{array}{l}.40 \\
(.17)\end{array}$ & - & $\begin{array}{l}.41 \\
(.15)\end{array}$ \\
\hline \multicolumn{7}{|l|}{ 6. 1978 Trend Shift Estimates: } \\
\hline (a) American & - & - & $\begin{aligned}-.009 \\
(.010)\end{aligned}$ & $\begin{array}{r}-.010 \\
(.010)\end{array}$ & $\begin{array}{r}-.007 \\
(.007)\end{array}$ & $\begin{array}{r}-.014 \\
(.008)\end{array}$ \\
\hline (b) Eastern & - & - & $\begin{array}{l}.005 \\
(.011)\end{array}$ & $\begin{array}{r}-.002 \\
(.015)\end{array}$ & $\begin{array}{r}-.007 \\
(.007)\end{array}$ & $\begin{array}{r}-.014 \\
(.008)\end{array}$ \\
\hline (c) Transworld & - & - & $\begin{aligned}-.003 \\
(.014)\end{aligned}$ & $\begin{array}{r}-.016 \\
(.017)\end{array}$ & $\begin{array}{r}-.007 \\
(.007)\end{array}$ & $\begin{aligned}-.014 \\
(.008)\end{aligned}$ \\
\hline (d) United & - & - & $\begin{array}{r}-.022 \\
(.018)\end{array}$ & $\begin{array}{r}-.029 \\
(.022)\end{array}$ & $\begin{array}{r}-.007 \\
(.007)\end{array}$ & $\begin{array}{r}-.014 \\
(.008)\end{array}$ \\
\hline $\begin{array}{l}\text { 7. Probability Value of Test for Unit } \\
\text { Output Elasticity }\end{array}$ & .64 & .32 & .44 & .97 & .59 & .96 \\
\hline 8. Standard Error & .050 & .058 & .043 & .057 & .046 & .059 \\
\hline
\end{tabular}

Note: Regressions included unrestricted airline-specific constants, unrestricted airline-specific trends, and dummy variables for strikes at Transworld (1973) and United (1975, 1979). Coefficients on lagged employment, departures, and available ton-miles are restricted to be equal across airlines. The sum of the coefficients on lagged employment and departures is restricted to unity. The probability values of the test for this restriction are reported in row 7 .

is easily accepted at conventional significance levels. ${ }^{17}$ The estimates differ somewhat between the two specifications, although they suggest that the largest increase in trend productivity growth occurred at United. The point estimates of the change in productivity at United imply that maintenance employment was approximately 20 percent lower in 1984 than it would have been in the absence of a shift in trend, although the estimated cumulative effect is imprecise, and insignificantly different from zero by conventional stan-

\footnotetext{
${ }^{17}$ The probability values of the test statistics for no shift in trend after 1978 are .46 and .35 , respectively, for the employment functions in columns (3) and (4).
}

dards. ${ }^{18}$ Apart from the distinction between secular and post-1978 productivity trends, the decompositions of employment changes associated with the specifications in columns (3) and (4) are very similar to those presented in Table 6.

Finally, the last two columns of Table 5 present employment functions estimated

\footnotetext{
${ }^{18}$ In a first-order autoregressive model with a coefficient of $\lambda$ on the lagged dependent variable, the effect of a change in trend of $\delta$ percent at some reference period yields a cumulative effect of $\delta[t+$ $\left.(t-1) \lambda+(t-2) \lambda^{2}+\ldots+\lambda^{t-1}\right] t$ periods later. Over a six-year interval, the cumulative effect is $7.2 \delta$ if $\lambda=$ 0.2 and $8 \delta$ if $\lambda=0.3$. A rough estimate of the standard error for the cumulative effect can be obtained by multiplying the standard error of the estimated trend shift $(\delta)$ by the appropriate cumulative factor.
} 
Table 6. Decomposition of Employment Changes, 1978-84, Assuming No Change in Trend Productivity Growth.

\begin{tabular}{|c|c|c|c|c|c|c|c|c|}
\hline \multirow[b]{3}{*}{ Source } & \multicolumn{6}{|c|}{ Predicted Percentage Changes in Employment ${ }^{\mathrm{a}}$} & & \\
\hline & \multicolumn{2}{|c|}{ American } & \multicolumn{2}{|c|}{ Eastern } & \multicolumn{2}{|c|}{ Transworld } & \multicolumn{2}{|c|}{ United } \\
\hline & $(1)$ & (2) & (1) & (2) & (1) & (2) & (1) & (2) \\
\hline 1. Change in Departures & .4 & .2 & -2.5 & -4.0 & -33.6 & -35.2 & -10.8 & -11.2 \\
\hline $\begin{array}{l}\text { 2. Change in Flight } \\
\text { Length }\end{array}$ & 1.4 & - & 2.8 & - & 1.5 & - & 2.7 & - \\
\hline $\begin{array}{l}\text { 3. Change in Seats per } \\
\text { Aircraft }\end{array}$ & 7.2 & - & 8.3 & - & 15.7 & - & 7.1 & - \\
\hline $\begin{array}{l}\text { 4. Change in Ton Miles } \\
\text { per Departure }\end{array}$ & - & 6.0 & - & 12.1 & - & 12.3 & - & 8.9 \\
\hline 5. Trend Productivity & -6.7 & -4.3 & -6.3 & -4.4 & -11.4 & -3.5 & -15.0 & -15.1 \\
\hline $\begin{array}{l}\text { Total Predicted Change } \\
\text { in Employment }\end{array}$ & 2.3 & 1.7 & 2.3 & 3.7 & -27.8 & -26.4 & -16.0 & -17.4 \\
\hline $\begin{array}{l}\text { Actual Change in } \\
\text { Employment }\end{array}$ & \multicolumn{2}{|c|}{-2.3} & \multicolumn{2}{|c|}{1.4} & \multicolumn{2}{|c|}{-27.4} & \multicolumn{2}{|c|}{-18.0} \\
\hline
\end{tabular}


predicted changes in column (1) correspond to the estimated model in column (1) of Table 5, while the predicted changes in column (2) correspond to the estimated model in column (2) of Table 5.

under the hypothesis of a uniform shift in trend productivity growth at all four airlines. Again, the estimated trend shifts are imprecise and differ somewhat depending on specification. Controlling for flight length and aircraft size, the estimated shift in productivity growth is .7 percent per year, implying a cumulative effect in 1984 of about 6 percent. Controlling for ton-miles, the estimated shift is slightly larger, implying a cumulative effect of about 10 percent in 1984. These estimates suggest that maintenance employment at the four largest trunks in 1984 was 5-10 percent lower than would have been predicted on the basis of pre- 1978 trends. Because of the short time period since deregulation, however, it is difficult to obtain a precise estimate of the trend change in 1978, and the data are statistically consistent with no change in productivity growth rates.

The estimates in Table 5 and the decompositions in Table 6 suggest two conclusions. First, if deregulation has caused an increase in productivity growth rates, the effect has been relatively small. Second, the major components of employment change for the four largest trunk airlines are declining departure activity (for Trans- world and United) and secular productivity growth. These effects have been partially offset by increases in aircraft size and flight length, with relatively small net changes in employment at two of the trunks (American and Eastern).

On the basis of these conclusions, it is possible to estimate the effect of deregulation on maintenance employment at the trunks by calculating their relative output losses since 1978. Between 1978 and 1984, the growth rates of departures and tonmiles for the industry as a whole exceeded the respective rates at the trunks by 17 and 18 percent. ${ }^{19}$ Assuming a unitary elasticity between employment and output, as suggested by the estimates in Table 5, employment would have been 15-20 percent higher at the trunks in 1984 if they had retained their pre-deregulation share of industry output. If, in addition, deregulation increased the rate of growth of maintenance productivity as suggested by the point estimates in Table 5, then employ-

\footnotetext{
${ }^{19}$ Industry scheduled departures were 50,403,000 in 1978 and $56,162,000$ in 1984. Scheduled departures at the 11 incumbent trunks were $3,509,000$ in 1978 and 3,195,000 in 1984 .
} 
ment would have been at most $20-30$ percent higher at the trunks in the absence of deregulation.

Combining these estimates with an estimate of the wage gap between the trunks and the smaller airlines yields an estimate of the effect of deregulation on the earnings of mechanics in the airline industry. Evidence from industry wage surveys and union contracts at the smaller airlines suggests that the hourly wage gap between the trunks and other airlines was relatively small in 1984: perhaps no more than 25 percent. This gap is consistent with the difference between new-hire rates and established rates in two-tiered contracts recently introduced at many of the trunks, and with the magnitude of wage concessions recently negotiated at several of the trunks. It also represents the historical gap between mechanics' wage rates at the trunks and average hourly earnings of maintenance mechanics in manufacturing industries. Assuming a maximum 25 percent hourly wage differential, employment losses at the trunks attributable to deregulation reduced total average annual earnings of maintenance workers in the industry by approximately 5 percent below the level that would have prevailed in the absence of deregulation.

\section{Summary and Conclusions}

Deregulation of the airline industry has had a strong impact on the level of flight activity and the profitability of the trunk airlines. ${ }^{20}$ For airline mechanics at these airlines, however, the main effect of deregulation has been to reduce employment. Although contracts at several of the trunks cut wages at the end of 1983, mechanics' real and relative wage rates were remarkably stable in the first five years of deregulation, a pattern consistent with the

\footnotetext{
${ }^{20}$ For example, Delta Airlines suffered operating losses for the first time in its history in 1982. Braniff, Continental, Eastern, and Western, which all earned operating profits from 1970 to 1978 , sustained large operating losses from 1980 to 1983. By comparison, USAir earned significantly higher operating profits after 1978 than before.
}

behavior of mechanics' wages before deregulation.

Reductions in maintenance employment at the trunks since 1978 can be attributed to several different factors, including secular productivity growth and changes in output. An analysis of the employmentoutput relationship reveals small but imprecisely measured increases in the rate of growth of productivity following deregulation. An analysis of output shares, on the other hand, reveals a 10 percentage point drop in the share of flight activity at the trunks since 1978. This loss in output share is equivalent to a $15-20$ percent reduction in maintenance employment at the trunks, or a transfer of 5,000-7,000 maintenance jobs from the trunks to the smaller airlines. Because the wage gap between the trunks and the other airlines in the industry is small, the effect of this transfer on the average hourly earnings of mechanics in the industry is small-at most, 5 percent.

Deregulation may have affected pilots' earnings more than the earnings of airline mechanics. ${ }^{21}$ Compared to mechanics' earnings, however, historical differentials among pilots' earnings at the trunks were relatively large. Moreover, pilots have relatively fewer employment opportunities outside the airline industry than mechanics. These differences raise an important hypothesis for further research: is the effect of product market deregulation on wages or earnings related to the historical structure of wages in the affected industry or the gap between wage rates in that industry and wage rates for similar workers in other industries? The experience of the airline mechanics suggests that the impact of deregulation is small when interfirm and interindustry wage differentials are small. More detailed comparisons among pilots, flight attendants, and mechanics could provide useful evidence on this hypothesis.

\footnotetext{
${ }^{21}$ According to BLS industry wage surveys administered in 1975,1980 , and 1984, average gross monthly earnings of captains and the corresponding coefficients of variation of captains' earnings were $\$ 4,314$ and .15 in 1975 ; $\$ 6,877$ and .19 in 1980 ; and $\$ 8,154$ and .29 in 1984. In 1967 dollars, these average earnings levels were $\$ 2,676$ in $1975, \$ 2,786$ in 1980 , and $\$ 2,621$ in 1984 .
} 


\section{REFERENCES}

Bailey, Elizabeth E., David R. Graham, and Daniel P. Kaplan

1985 Deregulating the Airlines. Cambridge, Mass. MIT Press.

\section{Cappelli, Peter}

1985 "Competitive Pressures and Labor Relations: The Response of the Airline Industry." Paper presented for the Second Annual Berkeley Conference on Industrial Relations, February.

Cordes, Joseph, Robert Goldfarb, and Richard Johnson

1984 "Normative and Positive Aspects of Job Loss Compensation for Airline Employees." Unpublished manuscript, October.

Dertouzos, James N., and John H. Pencavel

1981 "Wage and Employment Determination
Under Trade Unionism: The International Typographical Union." Journal of Political Economy, Vol. 89, No. 6, pp. 1162-81.

Hendricks, Wallace, Peter Feuille, and Carol Szerszen

1980 "Regulation, Deregulation, and Collective Bargaining in Airlines." Industrial and Labor Relations Review, Vol. 34, No. 1, pp. 67-81.

Northrup, Herbert R.

1983 "The New Employee-Relations Climate in Airlines." Industrial and Labor Relations Review, Vol. 36, No. 2, pp. 167-81.

\section{Pencavel, John $\mathbf{H}$.}

1984 "The Trade-off Between Wages and Employment in Trade Union Objectives." Quarterly Journal of Economics, Vol. 99, No. 2, pp. 21532 